\title{
Cem DOĞAN
}

Dr. Öğr. Üyesi | Assist. Prof. Dr Iğdır Üniversitesi, Fen Edebiyat Fakültesi, Tarih Bölümü, Iğdır-TÜRKIYY Iğdır University, Faculty of Science and Letters, Departmant of History, Igdir-TURKEY

ORCID: 0000-0002-2008-3830

dogancem1@hotmail.com

\section{Bounds of Passion: Adultery, Gender and Modernization of Penal Practices in Ottoman Society From the Classical Age to 1915}

\begin{abstract}
Adultery (zina $)$ as a sexual act is a double-edged affair that plays a prominent part in reshaping the legal and social image of both the adulterer and the cheated person. Besides being a social phenomenon, adultery is a process that transforms people into objects of positive law. Throughout history, various sanctions have punished adulterers, and compensated those who violated the rights arising from family ties. Punishment for adultery, which sometimes reveals itself as exposure, violence or execution, has gained a more secular character with the progress of contemporary legal systems. Thus, the strict attitude of the Middle Ages and the early modern period on sexual crimes have gradually softened because of the transformation in law. From the viewpoint of the Ottoman criminal code, which nourishes on the Islamic heritage, adultery had to bring about a fine, but there were still some cultural forms directed at displaying, which would humiliate adulterers in society without discrimination between men and women. With the Tanzimat period, on the other hand, principles of the Western countries became the origin of the modernization of Ottoman law system. This scene influenced the parameters that furnished the juridical content of infidelity in the manner of those extracted from Western law by overlapping with it. This study shall seek to discover the social and legal roots of the modifications regarding adultery and family institution in terms of Ottoman criminal act from the classical age to 1915.
\end{abstract}

Keywords: Ottoman Empire, Adultery, Shari'ah, Gender, Penal Code.

\section{İhtiras Bağları: Klasik Dönemden 1915’e Osmanlı Toplumunda Zina, Toplumsal Cinsiyet ve Ceza Pratiklerinin Modernleşmesi}

Öz

Cinsel bir edim olarak zina hem zinacıya hem de aldatılan kişiye ilişkin hukuksal ve toplumsal algının yeniden şekillenmesinde kayda değer bir rol oynayan çift uçlu bir meseledir. Zina toplumsal bir olgu olmanın yanı sıra bireyleri pozitif hukukun nesnelerine dönüştüren bir süreçtir. Tarih boyunca ülkelerin hukuk gelenekleri çerçevesinde yürürlüğe konulan muhtelif müeyyideler bir yandan zinacıları cezalandırmış, diğer yandan da aile bağlarından doğan hakları ihlal edilenlerin zararlarını tazmin yoluna gitmiştir. Kimi zaman teşhir, şiddet veya idam biçiminde tezahür eden zina cezaları modern hukuk sistemlerinin gelişmesiyle daha seküler bir karakter kazanmıştır. Böylece, Orta Çağ’ın ve erken modern dönemin cinsel suçlar konusundaki katı tutumu hukuktaki dönüşümün bir neticesi olarak tedricen yumuşamıştır. Meseleye büyük ölçüde İslami gelenekten beslenen Osmanlı ceza hukuku açısından bakıldığında, zinaya daha ziyade para cezasıyla mukabele edildiği ancak teşhire yönelik, zinacıları kadın-erkek ayrımı yapmaksızın toplum içinde aşağılayacak birtakım kültürel tahkir mekanizmalarının da uygulamaya konulduğu görülür. Öte yandan, Tanzimat dönemiyle birlikte Osmanlı hukuk sisteminin modernleştirilmesinde Batılı ülkelerin getirdiği temel ilkeler hareket noktası olarak alınmaya başlamıştır. Bu durum ise geleneksel Osmanlı hukukunda zinanın yasal içeriğini dolduran başlıca parametrelerin Batı hukukundan iktibas edilenlerle çakışmasına yol açmıştır. Bu çalışma, klasik dönemden 1915’e kadar geçen sürede Osmanlı ceza hukuku açısından zina ve aile kurumuna ilişkin değişimlerin toplumsal ve hukuksal izlerini sürmeye çalışacaktır.

Anahtar Kelimeler: Osmanlı Devleti, Zina, Şeriat, Toplumsal Cinsiyet, Ceza Hukuku. 


\section{Introduction}

Sexual acts have always been a focus point through the history of penal codes, and Islamic/Ottoman canon is not outside of this wide and colorful circle. Yet, we still know little about the sexual orientations and choises made by Ottoman women and men in detail, even though some bold researches has been made in recent times. When we think of delving into the intricate structure of sexual desires and deeds in Ottoman society, we should probably begin by drawing a line between the classical age and modern times. In the Ottoman classical age, indeed, the law concerning sexuality was a mix of the rules written in the shari' $a$ and traditional moral codes in the society (örfi bukuk), but in the later years of the Empire, law system started to change in favour of the Western modern law systems. Naturally, new ways of approaching to sexual offences like prostitution, adultery, sodomy emerged in rapport with their Western counterparts.

Adultery ( qina $^{-}$), on the other hand, kept its existence as a crime which could lead a family to falling apart. It does not mean that the authorities turned a blind eye to other sexual offences, but they clearly prioritized zin $\bar{a}$ ' because of its destructive structure in terms of both moral and social conditions. Violation of moral and sexual roles was a clear threat to the social body and law system itself. Besides, zin $\vec{a}$ ' was an open invitation for the infringement of traditional dearness of the purity of lineage. Therefore, it was not only a peril-point in the sense of sexual ethics but also a tangible menace to the general population in the Empire.

Penal discourses for infidelity in the classical age used to occur in some certain ways, like exposuring, using violence on the offender, even sometimes execution. However, Westernization reshaped the perception of law and as a result of changing trends in the Ottoman legal thought and approached adultery in a milder attitude. No matter how the physical punishments carried on their very existence, they began showing a falling tendency in a long shot. This paper aims to discuss the changing nature of law and what zina $\vec{a}$ meant for people as well as legal experts in Ottoman society, from the classical age to the year of 1915 .

\section{Defining Zinā': A Theoretical Framework and the Problem of Diagnostics}

Sex is, paradoxically, both the most private and intimate act humans can undertake and profoundly social activity. All societies and cultures regulate sexual activity among their members. Certain pairings are permissible, while others are not; some acts are permitted, while others are forbidden. Muslims are not alone in making distinctions between what is permissible and illegitimate, what is proper and improper. Nor have Muslim societies historically been unique (or uniform) in imposing consequences, including physical chastisement, on those who break the rules (Ali, 2006: 56).

In this context, zin $\bar{a}^{\prime}$ might be considered one of the most archaic and complicated social, moral and juridical issues. It is a social problem because of the bloodline uncertainty. Also, it is a moral issue, because it explicitly defies the traditional and sacred rules and damages the rights of life-partners who has been cheated. And it is subsequently a juridical matter of which in terms on what grounds authorities would discipline the perpetrators and how the crime is verified.

To exemplify, adultery in Ancient Egyptian law; was regarded as an abuse of the rights of others and public morals, asit likewise causes degeneration. And so, the sentence is based mostly on cutting the reproductive organs of the fornicators. The punishment for this transgression was too heavy in ancient Roman law as well. At first; women were seen as the mere criminal and sentenced up to death. But then, men also started being penalized with exile and confiscation of their wealth. Jews who were exposed to a religious law assumed the penalty of death fit for the adulterers according to the Torah's rules (Mutaf, 2008: 575).

The punishment for the crime of adultery (zina $\bar{a})$ is the most acute of all forfeitures under the shariah. Its sanction aims to secure the most essential and vital organization in society-the family. 
If committed by an unmarried individual, the sanction is 100 lashes, and in a great deal of jurists' opinion, for a married person the fornicator must be stoned to death (rajm). Stoning the married adulterer is supported by all four leading schools of Islam, and while not in Qur'an, the punishment has been enforced by the Prophet since the initial periods of the installation of the shari'ah against Muslims and Jews adhered to ever. There are, however, significant minority views that question or deny the punishment of stoning based upon sources that clarify the crime warrants 100 lashes only, applicable to everybody equitably (Korbatieh, 2018: 3). Bouhdiba, (1975: 30-31) sought to show the bottom line of this act:

Anything that violates the order of the world is a grave 'disorder', a source of evil and anarchy. That is why, zinā arouses such strong, unanimous condemnation. However, in a sense, zinā still remains within the framework of order. It is a disorder in order: it does not, strictly speaking, violate the fundamental order of the world; it violates only its modalities. It is, in its own way, a form of harmony between the sexes. It is a false nikāh, not an antinikāh. It recognizes the harmonious complementarity of the sexes and its error lies in wishing to realize it outside the limits laid down by God.

The second verse of the Surah an-Nûr ordered that: "Hit 100 sticks on each of the men and women who committed adultery". According to this verse, women and men who commit adultery are punished with a hundred wands. It is crucial for them to do the act of zina ${ }^{\prime}$ with their consent to get a punishment (Akbulut, 2003: 174), notwithstanding that zin $\vec{a}$ has a complex structure in Islamic code. Unlawful intercourse is described in the shari'ah as all acts of sexual penetration other than those between a married couple or a master and his female slave (Tucker, 2009: 327). But it is clear to see that there is a contrast between the theological framework and physical life in terms of qina '. Because no matter how zina $\vec{a}$ was distinguished as a right of God, but not the man, it should be penalized justly for both men and women; fuqahä' interpreted it in favor of men. There are substantial disagreements, though, among schools and jurists within each school as to the conditions required for an accurate statement and testimonial evidence (Hosseini, 2011: 14.

Adultery can be confirmed not merely by a witness but also by statement. However, the effect of the acceptance on the sentence depends on its fulfillment by both men and women. The fornicator must be a psychologically normal and mature individual. The confirmation of a drunk man is not binding. A similar method to the regulation on witnesses also applies to admissions; the affirmation must also be renewed four times at various hearings (Temiz, 2014: 497).

\section{Ottoman Moral and Civil Codes on Zinä' in the Classical Age}

Particularly medieval practice of figh attempted to broaden the perimeters of lawful sexual intercourse. Thus, fuqaha $\vec{a}$ draw a current picture to tolerate men marrying or concubinage with their slave-women, even if Qur'ān says for zinā' that it must be punished when it is performed by either sex (24: 3). While the Qur'ān mentions slave-women were regarded as eligible as spouses, medieval figh struggled to get it outside the criteria of zin $\bar{a}^{\prime}$ (Sonbol, 2003: 7). As being one of the greatest sins, ₹in $\bar{a}^{\prime}$ has been put in the category of budud according to the schools of legislation. In this sense, it can not be diminished, increased, altered, or commuted by anyone (Sonbol, 1997: 216217).

As Peirce points out, it was likewise problematic to provide four witnesses required to engage in adultery or all forms of illicit sexuality, but this legal loophole in both the shari'ah and the rules was packed with circumstantial evidence (Peirce, 2003: 111). What makes the crime of zina $\bar{a}$ more problematic is that the intention factor in this crime becomes the key to indictment, it reveals a double standard for sexual crimes in Islamic order and Ottoman code in particular. The demand of four eyewitnesses, which is mandated in both the Qur'ān and several hadiths of the prophet Muhammad, was a shield against allegations of zin $\bar{a}$. These rules are set aside, leaving room for 


\section{DOĞAN, Cem (2021). "Bounds of Passion: Adultery, Gender and Modernization of Penal Practices in Ottoman Society From the Classical Age to 1915", Mavi Atlas, 9(1): 42-54}

false accusations that give less legal protection to the accused (Semerdjian, 2006: 195-196). The accusation of zin $\bar{a}$, which could be turned into a crime under the title of qaif if the accuser was not capable of certifying his/her allegation, had a great possibility to get severely punished, too. Qadi registers are teemed with counter claims and hadd or ta'zir punishments. In such a case, a man named Mehmed b. Mustafa Zernişânc1 accused his father with fornication, but he could not prove his allegation (Qadi Register of Bâb Court, no: 54, 1691). Therefore he was punished with hadd-i karf, which is declared in Qur'an (sûrah al-Nûr, 24: 4) by flogging with eighty stripes (Quran, 2004: 401).

The consequence of qaif did not change even if the false accusation of zin $\vec{a}$ took place as a word of insult. We can see a clear example of it in the qadi registry of Istanbul Court between the years of 1765-1767. The suitor here was Âişe bint-i el-Hâc İsmail who litigated for complaining about el-Hâc Salih bin el-Hâc Ali. Âişe said in her claim that Salih came her home and cursed her as she was a brothel-keeper-lady (kârbâneci), whore (orusbu) and declared that banished from her hometown because of her qinäa' (vilâyetinden fi'l-i șenî‘ ederek geldin deyü bi'l-mwvâcehe șetm etmekle...) (Qadi Register of Istanbul Court, no: 76, 1765-1767). Âişe Hatun adopted a decent manner and took the incident to the presence of local qadi with her two male witnesses as had been ordered in the shari'a, but then another problem emerged in the court. Âişe Hatun was known as an impure woman (mezbûre Aise afîfe olduğu müteyak.kin olmayıp) and this situation should have been considered in terms of Salih's punishment. Finally, qadi decided to lower the level of hadd punishment to ta'zîr for Salih (Qadi Register of Istanbul Court, no: 76, 1765-1767.

In Ottoman society, which had a patriarchal character, adultery of women called for a harsher forfeiture than adultery of men. As a matter of fact, woman belonged to a man, and by committing the crime of infidelity, the impasse of man's honor was ruined. Especially if the woman was a Muslim, her punishment was even more severe. As Metin And stated, such a woman was often put on the back of a donkey or horse with a cattle tripe on her head and exposed in the streets of the city (And, 2009: 228-229).

There is no doubt that the woman was cursed and spitted on her face to express her infamy, or she was stoned by the people during this forced city tour. This punishment was also applied to men. In the accounts of the Austrian ambassadors who were in Istanbul in the 16th century, it is stated that those who committed adultery were immediately roamed and exposed on a donkey, but no yoke was hung around their necks. In contrast, if Turkish men were captured with a Christian woman or Christian women with a Turkish man, the criminals have been drowned or dangled from a hook (Tebly, 2013: 208).

Evliya Çelebi mentions a Gypsy branch that illustrates this event in his notes. Even if it is imaginary, a woman apprehended with a Jewish man is placed on a donkey and dirty tripe is wrapped around his head. Also, the male is put on another donkey that moves with him (Evliya Çelebi, 1996: 308). Such a manner of suffering in the public sphere, of course, had drastic effects for the woman. Since she was now a cheating woman, and because of this condition, she principally fit in the public sphere. The man's guilt, though, disappeared after a while, as he was considered a sexually rapacious breed. Penalties like this probably lasted well into the modernization era.

Although the crime of adultery imposed a merciless punishment following the inherited legal axiom, the judges followed a proper conciliation order converting the stipulated punishment to payment (Tucker, 1998: 181). An approach such as fines for adultery, which was seen in the regulations of the classical period, disappeared. Although arguable in terms of the law, it is intriguing to observe that the classical Ottoman practice of control established some payment fines for infidelity and the exposure penalty, in terms of the plaintiff's making a definite profit and contributing to the social distribution of wealth. Like Arpaci discusses, although the body became the focus of political relations and morals was a stage that took place before the industrial society, 


\section{DOĞAN, Cem (2021). "Bounds of Passion: Adultery, Gender and Modernization of Penal Practices in Ottoman Society From the Classical Age to 1915", Mavi Atlas, 9(1): 42-54}

its subjugation to the penal economy is likewise recently dated to this stage (Arpac1, 2012: 136). Fatih Kanunnâmesi, for instance, determines that if a married individual commits adultery, $\mathrm{s}(\mathrm{he})$ would pay off 300 coins if he owns a wealth over 1.000, 200 coins when he has 600 , if his money is under 600, he would pay 100, 50 and 40 respecting his monetary condition (Uçok, 1947: 52).

Here, introducing financial fines on sexual transgressions explains the utilitarian view of the classical period Ottoman juridical system, since it is too against the order of the shariah. There is no provision in the Islamic criminal law regarding that a monetary sanction can be considered adultery or prostitution included in its scope. However, the classical period Ottoman authority, by promoting the law arbitrarily, made a kind of tariff in response to these crimes in a more opportunistic manner. For example, the following expression about adultery is used in a code text from the time of Suleiman the Magnificent:

If a Muslim commits adultery and if it is certain with shari'ah, and if (s)he is married and capable of paying 1000 coins or more, $\mathrm{s}(\mathrm{he})$ shall pay 300 coins; and if he is a middle-class person and $\mathrm{s}(\mathrm{he})$ has 600 coins, $\mathrm{s}(\mathrm{he})$ shall pay 200 coins; and if s(he) has 400 coins, $\mathrm{s}(\mathrm{he})$ shall pay 200 coins; and $\mathrm{s}(\mathrm{he})$ has less, $\mathrm{s}(\mathrm{he})$ shall pay 50 coins; and if $\mathrm{s}(\mathrm{he})$ is dead-poor, $\mathrm{s}$ (he) shall pay 40 coins (Kanunname-i Âli Osman, 1913: 1).

As can be figured out from the quote, Ottoman code in the classical period approaches the crime of adultery more pragmatically. It mediated the production of a supplementary source of income mechanism by specifying monetary penalties for perpetrators. In this context, by siding with Dursteler, it can be argued that although political forces, inquisitions or mufti sought to set the limits of orthodoxy and unchangeable lines on behavior, dresses, food and social practices, in real world, these lines were permeable and could be made in all directions (Dursteler, 2012: 158159).

No matter how Özkorkut (2007: 90) alleges that there is no contrast between men and women concerning adultery in the Codes of Fatih and Kanuni, and it seems so, we may argue that the clause of kanunname above was performed for men, but not women. Most women, if not all, did not have the chance to take part in the dynamic work life because of the social organization in Ottoman society, and therefore, they could not make money for maintaining an independent life from their husbands. They had to base their income upon their spouses and look after the children with the housework. It means that they had no choice to meet their fine of adultery.

There is a noticeable point in the kanunnames, though, that needs a particular touch here. As we know, the oldest Ottoman penal code that existed until today is the one which belongs to Sultan Mehmed, the Conqueror. The initial chapter of this text deals with zina $\bar{a}$, the second one homicide and wounding, and the third one wine drinking, theft and slander. Second legislature has been declared during the reign of Sultan Bayezid. This kanunname also mentions zina $\bar{a}$ in its first chapter (Akman, 2005: 489).

It is also possible to view the functional attitude of classical Ottoman criminal law not merely in adultery crimes but also in cases of adultery slander. Within the crime of defamation, which is called qazf by Islamic law, a woman or a girl would verify it by a witness if a man claimed that he had committed adultery and the man also denied it. If a woman or a girl could not offer a witness, she would be sworn by a man, if she held a pledge, she would be convicted to whips, injuries or fines as a woman or girl (Alyot, 2008: 26).

In the classical period of the Ottoman Empire, there were some severe punishments, which are often seen as ruling based on sexual relations between a Muslim woman and a non-Muslim man. An adultery incident in Tripoli, which Galland recorded in his memoirs of 1673, proves this. A Mesina man residing in Tripoli was detected in a sexual relation with a local Muslim woman and was first drowned, later thrown over the walls and ultimately burned (Galland, 1998: 16). 
Gravure 1: Exposure of an adultress. See. Metin And, 16. Yü̈ynlda İstanbul: Kent-Saray-Günlük Yaşam. İstanbul: Yapı Kredi Yayınları, 2009, s. 228.

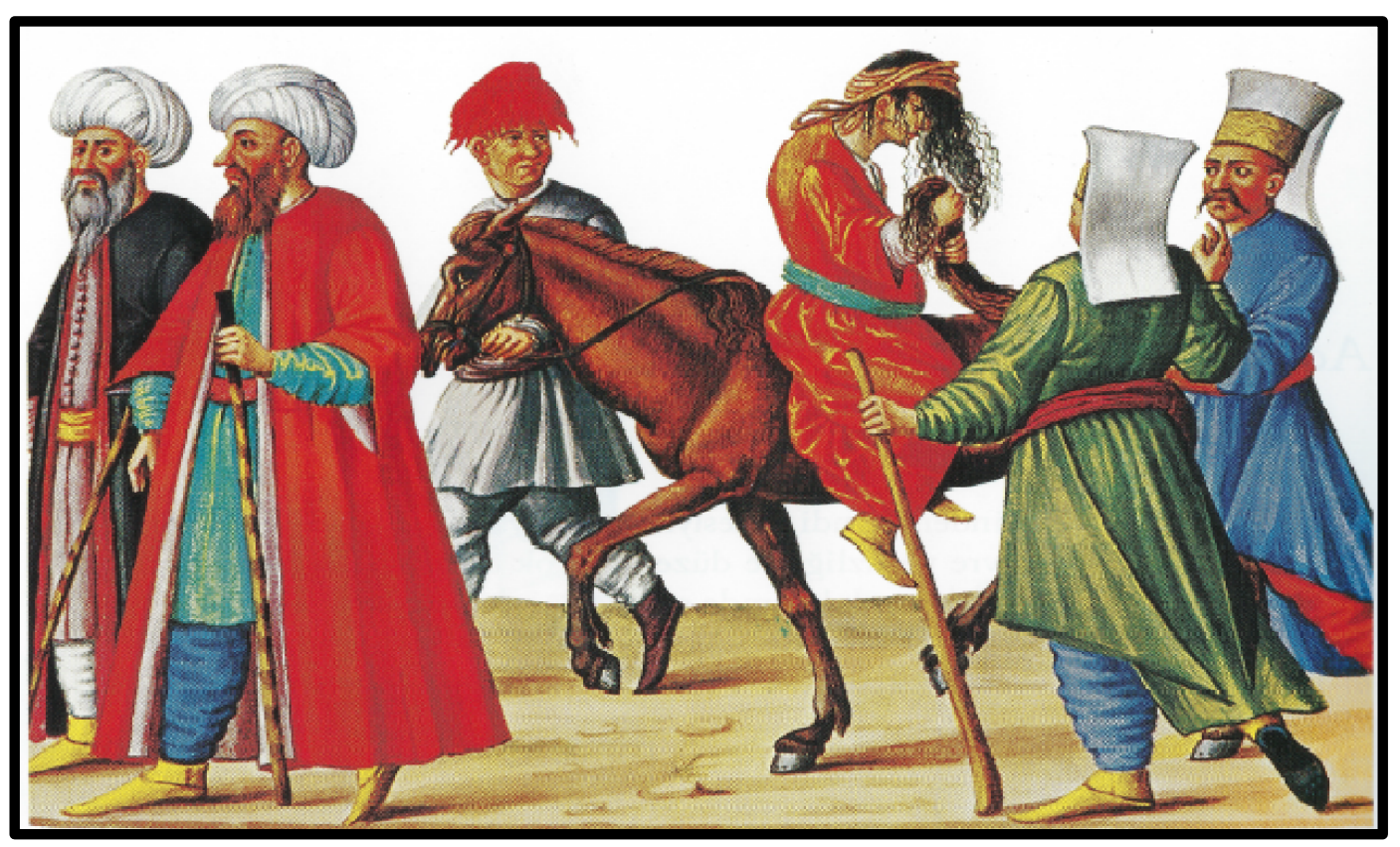

However, the sultan or bureaucratic elites could apply violent treatment of adultery and similar sexual crimes in the modernization era. Towards the end of the nineteenth century, an observer who recorded under the pseudonym Wanda, reported with astonishment that the sultan sometimes set religious rules aside and resorted to personal judgment. According to her account, one day a woman who committed adultery was brought to the sultan's presence. The Sultan once ordered the woman to be put in a barrel and thrown into the chilly and calm waters of the Bosphorus, akin to the punishment of being put in a sealed sack for another adultery (Wanda, 1884: 27). We, on the other hand, must underline that there was almost no difference between inina and prostitution cases oftenly, because of the hardship of proving whether an illegal sexual act was a zina $\vec{a}$ or fuhs (prostitution).

The one and only occasion in Ottoman history proving that the sanction of infidelity in Islam was to execute by stoning taken place in 1680 in Aksaray, Istanbul. A Muslim woman, whose husband was on a trip, was arrested red-handed while committing adultery with a dhimmi young man who paid for sericulture. Because of the trial, it was agreed that the man would be executed while the woman was stoned. Although the non-Muslim fellow converted to Islam regarding the suggestion, no matter how he struggled to escape the punishment, his fate did not change. The woman said: "He is slandering me on this issue, I have no guilt. Do not mince your princes, set me free" (Karaçay Türkal, 2012: 731-732). But she had fruitless attempts and beggings Mehmed IV, and, she could not evade being wasted. It was her brother who threw the first stone at zaniye (Akyavaş, 1950: 347). An analogous case illustrated in Tarib-i Selanikî can be brought up here. According to this:

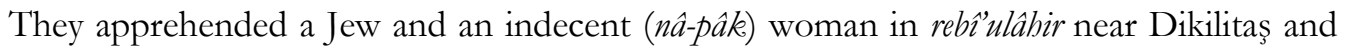
put the woman into a sack (girâra koyup) hung her by the throat. They also hung the Jew. When the Jews arrived to pick up the corpse, one of them was crushed by the conscript boys (acemi oğlanlari) and they mauled the hanged-one's body, and then they put the lifeless body in a sack and put it on their back (Selânikî Mustafa Efendi, 1999: 715). 
Gravure 2: Exposure of an adulterer. See. Metin And, 16. Yü̈ynlda İstanbul: Kent-Saray-Günlük Yaşam. İstanbul: Yapı Kredi Yayınları, 2009, s. 229.

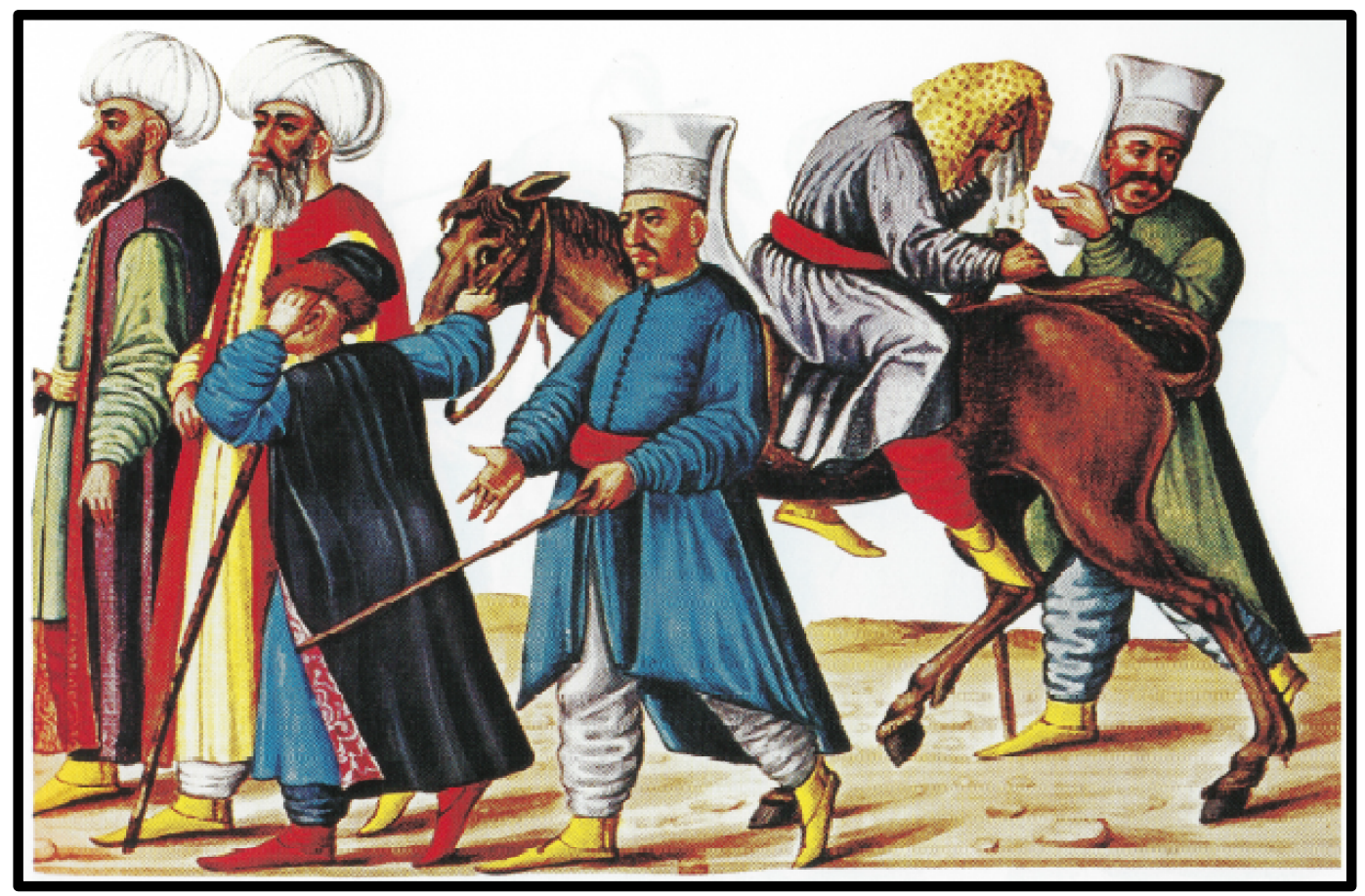

As is seen in the passage, this example happened in a reflexive way and ended up with a lynching party. Once people realized that a zin $\bar{a}$ ' occured between a non-Muslim man and Muslim woman, which is undoubtedly so here, they pearl-clutched. Needless to say that as in other seventeenth-century communities that made adultery punishable by death, Ottoman society leaned toward special settlements or court-prescribed fines for a felony that called for the near-impossible corroboration of four eyewitnesses (Z1lfi, 2010: 71).

\section{Towards a New Society and Law: Zinä' in the Age of Modernization}

As Giddens said, for a long time being sexually virtuous was measured by a woman's defiance to give in to temptation. Sometimes, the capacity to allow particularly dating under the auspices of notables and some forms of institutional protection, such as forced marriages, also fueled this rejection (Giddens, 1992: 7). In brief, the notion of chastity was a property applying to the woman and the first-degree male relatives who took over her security particularly in the Eastern cultures. The woman's adverse action was deemed an antithesis of the property law, which was exceptionally dangerous. Perhaps the decency of a woman was a transcendent right that has been given to her before the men who had her custody. But his exclusion of this God-bestowed legacy also meant he was exposed a total segregation by her family and environment, because she trampled on her dignity first, and then the honor of the male and female populations with whom she related.

For a man, on the other hand, the measure of being chaste or decent was equal to being autonomous to a specific degree and being able to control his way of life, being tough, unyielding in the face of obstacles, and having a dominant authority over a family, a woman and the generations that breed from it. However, the situation is rather distinctive for women. The foremost condition for her to be chaste is "purity". Women, unlike men, have a remarkable potential for contagion. Also, sacrifice, obedience, and respect are expected from the woman as a future mother. Women who do not embrace a normative attitude of womanhood towards men in their family and those around them, who act freely and chiefly do not consider virginity, are barred 


\section{DOĞAN, Cem (2021). "Bounds of Passion: Adultery, Gender and Modernization of Penal Practices in Ottoman Society From the Classical Age to 1915", Mavi Atlas, 9(1): 42-54}

from communal living or the society stigmatized them with malfeasance, often subjected to crimes such as rape and abuse.

Fariba Zarinebaf emphasized that when a Muslim woman interacted closely with unrelated men, she was often accused of fornication (zina $\bar{a})$ and prostitution (fubuss). It is almost impossible to distinguish between women who committed fornication and those who were involved in prostitution through the official Ottoman Islamic court and police records. The shariah did not distinguish between fornication, adultery and prostitution, and the punishment often varied only under the religious affiliation, civil status (married versus unmarried), and the social status of the offender (freeborn versus slave). Men, however, could have sexual intercourse with their slaves, although women were prevented from doing so (Zarinebaf, 2010: 105). Within this scheme, Ottoman law often dealt with the crime of rape regarding the notion of adultery. In the classical era, the punishment of adultery was carried out as an exclusion of the culprits from the social sphere. There were of course other forms of correction besides this method of punishment. The infidelity of a Muslim man and a non-Muslim woman and the adultery of a Muslim woman and a non-Muslim man had rather different connotations for the Ottomans.

Rudolph Peters accurately stated that criminal codes produce an insight into what a society and its rulers thought as its core qualities (Peters, 2005: 1). In this sense, we may claim that criminal law reflects the conservation of values in society that are essential for sustaining balance and that can't be satisfactorily assured by private law. It targets socially harmful acts that are forbidden because they produce chief peril to society and vigorously interfere with interests provided for the order (Bezoušková \& Lojek, 2015: 281).

This change as punishment can be imputed to modernization of Ottoman legislation. Some sanctions seem to have kept their nature in bodily suffering. When it was considered that a nonMuslim named Boğos, who was originally from the Jewish community and subsequently included in the Armenian community, had a deed with an unscrupulous woman named Fatma. In consequence, Boghos had been executed, and the woman was to be beaten or exiled to another district. As it is understood from the document, Fatma was a prostitute and Boghos had entered the woman's house by force (B.O.A., HAT., 512/25098, 1838).

Boğos was hanged here, and the woman got a milder punishment was since the man was non-Muslim. However, it is interesting that the infidelity of a Muslim woman with a non-Muslim man was condoned for the woman. There is no ambiguity that Fatma nam fâcire as the phrase in the document was already a woman who was a prostitute. It was not assumed appropriate for this woman, who was performing prostitution as a profession, and therefore publicly owned, to receive a punishment that would deform her physically or lead to her total death (B.O.A., HAT., $512 / 25098,1838)$.

The hadd punishments, which are composed of seven acts as adultery (zin $\bar{a}$ ), slander of chastity (qa: $f$ ), drinking (shirb), theft (sirqat), interception (birabe-qat'-ı tariq), apostasy (riddet) and rebellion (bagy) (Akgündüz, 1999: 3) (all together cerâimü'l-hudûd) ought to be punished by some different physical executions. The punishments stipulated for adultery in Islamic criminal law are stoning if married, hitting a hundred sticks if single, and exile. When the crime of hadd is definitely fixed, a certain penalty must be imposed, if there is a situation such as doubt, confession and back down on witnessing, the penalty for adultery is abated. By determining the zina $\bar{a}$ ' difficult, the Islamic criminal law actually left the responsibility of the penalty to the family of the woman. In Ottoman society, family honor was associated with the decency of women. Put it differently, the woman who damaged the family honor could be murdered, courts based on the shari'ab in the empire would order a person who killed two people for adultery (relative of a woman) to be released with no punishment (Çabuk, 2020: 16). Hence, it is obvious why the crime of adultery carried out by 


\section{DOĞAN, Cem (2021). "Bounds of Passion: Adultery, Gender and Modernization of Penal Practices in Ottoman Society From the Classical Age to 1915”, Mavi Atlas, 9(1): 42-54}

the woman required a harsher punishment than that of the man. Those whose crimes of adultery and related violations are settled regarding a courthouse document from 1845:

According to the degree of their offenses men and women shall be beaten in front of the prison, by the officer with a knotless club who is raising the club to the level of his head, except the part of head and stomach and face and breast and genital areas while men are standing and women in the sitting position (B.O.A., C.ADL., 19/1161, 1845).

Perhaps the most remarkable feature of the description is that adulterous ones will be hit with a club will be displayed in front of the prison, that is, in a public space. An incident in the following year documented adultery in the act. According to this, a man called Boyac1 Vasil, one local of Balat, was captured in the act of adultery with Cemile, who is recognized to be a prostitute, near Çarşambapazarı. Cemile's friend Emine was arrested, because she watched for adultery (B.O.A., MVL., 68/55, 1846).

In this context, zin $\bar{a}$ ' had a legalizing link to the violence against women, too. Notions like iffet, ir: or namus were deemed fit for women rather than men, and thus, they provided a mechanism of male violence in society. An archival document from 1845 informs us that a woman by the name of Emine, who was the wife of Molla Mehmed had an affair with Serkis nâm żmmî, and, woman's son İsmail saw them fornicating (B.O.A., A.\}MKT.MVL., 1/76, 1845). There was no chance of deniability or claim of qaif (defamation of adultery) in this scene. After having seen his mother in such a derogatory position, the young man could not control himself to kill them both. İsmail immediately executed his mother with a rifle and turned his anger to the man, and he bashed him around before murdering the adulterer (B.O.A., A.\}MKT.MVL., 1/76, 1845).

Sometimes, suspicion of adultery was the basic reason of murder. In the following year of the incident above, Mehmed killed his sister Hatice on the doubt of zinā'. However, an important factor stepped in at this point, because Hatice was a virgin and allegedly Hüseyin defiled her (zin $\bar{a}$, ve bikrini izale ettirmissin diverek). Mehmed rampaged so much that he cut the aorta of her sister several times. After all, the court sentenced Mehmed to shackles and punished him with doing errands for one year (B.O.A., A.\}MKT.MVL., 2/94, 1846).

It is significant that an explicit discrimination is established between the infidelity of men and women in the legislation of the modernization era. In the Penal Code of 1858, a woman who committed adultery (irtikâb-ı fi'illi șen'-i zinâ eylediği tahakekuk eden hâtun) would be punished with imprisonment at least three months up to two years. However, the husband had a license to forejudge the trial of his wife by the consent of marrying her again (Ceza Kanunnâme-i Hümayunu, 1858: 89). The adultery of the man was considered more of an unusual situation. When he engaged adultery with another woman in the house where he lived with his wife, he had to pay from five golden medjidies to a hundred upon her complaint (Ceza Kanunnâme-i Hümayunu, 1858: 89).

This article bears a specific sense in terms of its content. As we observe, there was a micro detail tucked away in the sentence which shows that a man was punishable merely if he intended to do zina ' in his own home in which shared his rightful wife. So, there was a question of space in male adultery for giving rise to the double-standards in the juridical structure of zin $\bar{a}$.

An appendix which was delivered into the statute as influenced by the French Penal Code of 1810, separated from Roman Law by not accepting adultery as a felony, peculiar to the wife and considering the adultery of the husband as a crime, but in terms of both the constitution and enforcement of the crime, it was more in favor of the husband (Şensoy, 1942: 77-78). In article 188 of the Penal Code of 1858, it was said: "A person is partially excused who on capturing in the act of fornication his wife or a woman of his home, kills either the woman or the adulterer" (The Ottoman Penal Code, 1888: 81). 


\section{DOĞAN, Cem (2021). "Bounds of Passion: Adultery, Gender and Modernization of Penal Practices in Ottoman Society From the Classical Age to 1915", Mavi Atlas, 9(1): 42-54}

As pointed out above, in Ottoman society, women were predominantly determined with the private sphere envisioned as domestic. The man had a strong connection with the public sphere. An ideal organization considering the social division of labor could only be accomplished by preserving the public-private separation. Prostitutes were busy with a job that went beyond the limits of this dichotomy. Qualitatively, transferring sexuality, which makes up the most individual aspect of the intimate sphere, to the public sphere through prostitutes, whether through adultery or prostitution, provoked violent reactions from the Ottoman society.

There was likewise a considerable worry in state authorities' minds about the Muslim population of the empire beginning from the 19th century and it was not so difficult to interweave this issue with zin $\bar{a}$ ' or prostitution, because the first one was related to the illegitimate bloodline, and the latter had no consequences in terms of the same matter. These two acts could also be a menace to the public order. As Yaku Sami from the Yanya Bidâyet Court said:

Since it will be the chastity and dignity of a mother who makes her a faithful wife once and for all, she will be incapable of the defeat of the azlal and igwat that surrounded her. A child will be born because of her mistake. Her act often causes bloodshed by quarrels and disagreements between two men (Sami, 1910: 508-509).

Confirming Yaku Sami's comments, we can run into plenty of events in the archival documents. In 1861, a resident of Izmit, Osman busted his wife with İbrahim in the act of zina $\vec{a}$. İbrahim noticed that it was to be a bloodshed upon this unseemly scene and sought to take precedence in quarrel by drawing his gun but it flopped. Later, he tried to attack Osman with his knife (yatağan bıçağın çekerek) but cheated husband took his buckshot rifle (saçma memlû' tüfengini) on the purpose of self-defense and killed him. At first, this case was heard by fatwahane and it decided that there was no need to punish the killer husband (B.O.A., A.\}MKT.MVL., 123/100, 1861). Besides, the 186th article of the Penal Code (Kânun-ı Ceza) anticipated that "a person shall not be liable to any punishment who causes death or wounding in self-defense, either in protecting his life or in saving his honor or virtue from outrage" (The Ottoman Penal Code, 1888: 80). Eventually, Osman got away with murder, because the authorities sanctioned his acts.

We may speculate that the following years were the same in terms of the relation between the modern law and traditional patterns of behavior in the face of adultery. But, by the principle of desperate times and desperate measures, the state authorities felt obliged to undertake the duty of custos morum. ${ }^{1}$ Particularly, the decreasing number of male population because of the wars paved the way for state intervention, to women in particular, during the absence of pater familias. A lucid instance comes from the last days of 1912. Apparently, the government aimed at stopping the spreading zin $\bar{a}$ ' and prostitution cases, which they were nested together with sexual crimes. Authorities preferred to associate these two acts through the addition to the article of 201 th in the Penal Code, which was appended in 19 Rebiülahir 1281 (21 Eylül 1864):

An adulterer can only be accused by the husband, and in his absence by a guardian. A woman proved guilty of adultery shall be imprisoned for from three months to two years. But the husband may arrest the execution of the sentence by consenting to take back his wife. The accomplice of the adulteress shall equally be punished by imprisonment for from three months to two years; and, in addition, by a fine offrom five to 100 gold medjidies. The evidence which may be received against a man charged with such complicity apart from his being caught in the act, shall be that arising from his presence in the harem of a Mussulman, or from letters or documents written by him. This provision is, however, only applicable when an adulterer is accused by the husband or guardian; as for other acts of lewdness or seduction, the guilty persons shall, under ordinary circumstances, remain subject to the police regulations in force in the Ottoman Empire. A husband who keeps

\footnotetext{
${ }^{1}$ Ahlak bekçisi (y.n.).
} 


\section{DOĞAN, Cem (2021). "Bounds of Passion: Adultery, Gender and Modernization of Penal Practices in Ottoman Society From the Classical Age to 1915”, Mavi Atlas, 9(1): 42-54}

up an adulterous intercourse in his house, and is convicted thereof on the complaint of his wife, shall be punished by a fine of from five to 100 gold medjidies (The Ottoman Penal Code, 1888: 86-87).

As it is overtly seen in the passage, an adulteress (zâniye) could only be accused by her husband or guardians, but since they were away for the Balkan War, there was a need at some point to regulate the moral relations in the empire. In consequence, the authorities came to an understanding that they needed to protect the wives of who were called to arms at the moment. A document explains this as the fact that the consenting zinā' of the wives of recruited by the army would disgrace both their dignity and government's efforts to preserve their chastity. Therefore, a new addition to the last one to the 201 th article in the Penal Code should have been implemented. The new addition was: "A willful act of adultery (rzâen fïili șen'i zina à) of women whose husband or custodian is under the military duty begets the penal prosecution in the name of public order without the need of an indictment by her husband or custodian" (B.O.A., ŞD., 2818/19, 1912).

\section{Conclusions and Suggestions}

No matter how it seems tangled, it is also obvious that juridical verdicts concerning zina $\bar{a}$ was interwoven with the old hegemony of the shari'ah. Ottoman legal system was in transition throughout the long 19th century, and this process gave rise to the creation of a two winged law perception. On one side, the shariah was standing with its all resistance to the new law systems, however, the new tendencies and quests for ruling the society more effectively were pushing the limits of it on the other. That is to say that a new and symbiotic relationship between the old and the new was both used to come into collision and reconciliation in the empire. Needles to say that this bifurcated change affected the gender relations and the construction of gender identities in society.

It is crystal clear that the Ottoman judicial system has been built upon the idea of patriarchal traditions, and naturally, the protection of men was the essential aim of it. Ottoman men already formed a privileged class thanks to the principal arguments that had been put by the shariah. Moreover, public relations were organized by men to a great extent, including the production and distribution of wealth. In the classical age, conjugal infidelity represented both the power of the shari'ah and the puissance of sultan, who implemented traditional codes to equalize the balance in the society through kanunnames. In the Ottoman codex tradition, zina $\vec{a}$ had a specific and yet a complex ground, because it allowed for the state to create a slippery platform so that it could easily move between the public and private spaces.

The essential elements which criminalized a sexual act and exacerbated its consequences were not only related to the fact that they were representing a great $\sin$ in the eyes of the shariah, but more of a practical concern so as to keep the oppression on women under the reasonable bounds. Therefore, when we attempt to analyze zina $\bar{a}$ ' as a crime of passion, we also have to look at it to be related with illicit and intimate relations, sexual greeds, religious misdeeds, a harmful practice to the integrity of family institution and demographical degeneration, and finally as a regulative mechanism of gender roles in the society.

By the 19th century, though, authorities realized that they needed to define adultery in a more secular sense to catch the modernity. The old argument about the seduction of the devil had to be replaced with a new concept that refers more meaning to the civilization process. Male rapacity of sex should have set an explicit example of new moral codes instead of defining women as the inactive objects of seduction, but it did not happen that way. Above all, the new literature inspired by the West introduced a deal of European culture patterns to the Ottoman world. In this new cultural climate, women became the objects of manly desire who were to be gained by the merited ones. This connoted that the old duality between men and women in the area of law lingered on to the 19th century's social, sexual, legal, and political dimension beyond any doubt. 


\section{DOĞAN, Cem (2021). "Bounds of Passion: Adultery, Gender and Modernization of Penal Practices in Ottoman Society From the Classical Age to 1915", Mavi Atlas, 9(1): 42-54}

Academic papers concerning adultery usually have overlooked the dynamic inner structure of social relations and their authentic cultural implications. Leaving this indisposition aside, the trends of historiography in Turkey should consider to include the gender relations when the subject is zina $\bar{a}^{\prime}$ or similar sexual activities, because there is a close link between the transformation law system, psychosociological facts, and the moral symbolism of the 19th century. If we manage to understand the anxiety about social, moral and ethnic degeneration and the imagination that attribute the signs of malfunction in a healthy social body to the change of gender relations, we also may foresee that how the social processes have taken a new fullness of meaning.

\section{References}

AKBULUT, İlhan. (2003). "İslam Hukukunda Suçlar ve Cezalar", Ankara Üniversitesi Hukuk Fakültesi Dergisi, 52(1): 167-181.

AKGÜNDÜZ, Ahmet. (1999). "Kanunnâmelerdeki Ceza Hukuku Hükümleri ve Şer'î Tahlili”, İslami Arastrmalar Dergisi, 12(1): 1-16.

AKMAN, Mehmet. (2005). "Osmanlı Ceza Hukuku Çalıșmaları Üzerine Bir İ́cmal”, Türkiye Arastirmalar Literatür Dergisi, 3(5): 489-512.

AKYAVAŞ, Rag1p (1950). “Tüyler Ürpertici Bir Ceza: Recim” Resimli Tarih Mecmuası, 9: 345-347.

ALI, Kecia (2006). Sexual Etbics and Islam Feminist Reflections on Qur'an, Hadith and Jurisprudences, Oxford: Onewold Publications.

ALYOT, Halim (2008). Türkiye'de Zabıta: Taribi Gelişim ve Bugünkï Durum, Ankara: Emniyet Genel Müdürlüğü Yayını.

AND, Metin (2009). 16. Yüzyllda İstanbul: Kent-Saray-Günlük Yaşam, İstanbul: Yap1 Kredi Yayınlar1.

ARPACI, Murat (2012). "Modernitenin Eşiğinde Toplumsal Cinsiyet Rejimi: Pastoral İktidar, Beden Politikaları ve Evlilik", Doğu Bat: Toplumsal Cinsiyet, 16(63): 131-146.

BEZOUŠKOVÁ, Lenka \& Antonin LOJEK (2015). "Adultery and Fornication in Historical Perspectives", The Lanyer Quarterly, 5(4): 261-285.

BOUHDİBA, Abdelwahab (1975). Sexuality in Islam, Londra ve New York: Routledge.

Ceza Kanunnâme-i Hümayunu (1858). İstanbul: Takvimhâne-i Amire.

ÇABUK, Fehminaz (2019). "19. Yüzyılda Osmanlı Toplumunda Zina: Bazı Zina Vakalarında İşlenen Cinayetler Üzerine Bir Değerlendirme", İnsan \& İnsan, 7(23): 1-19.

DURSTELER, Eric R. (2012). Dönme Kadinlar: Toplumsal Cinsiyet, Kimlike ve Smorlar, çev. Deniz Koç, İstanbul: Koç Üniversitesi Yayınları.

EVLIYA ÇELEBİ (1996). Evliya Celebi Seyahatnâmesi: Topkapr Saray Bağdat 304 Yazmasmmn Transkripsiyonu-Dižini 1. Kitap, haz. Orhan Şaik Gökyay, İstanbul: Yap1 Kredi Yayınlar1.

GALLAND, Antoine (1998). İstanbul'a Ait Günlük Anular II 1672-1673, çev. Nahid Sırrı Örik, Ankara: Türk Tarih Kurumu Yayınları.

GIDDENS, Anthony (1992). The Transformation of Intimacy: Sexuality, Love and Eroticism in Modern Societies, Stanford: Stanford University Press.

HOSSEINI, Ziba Mir (2011). "Criminalizing Sexuality: Zina Laws as Violence Against Women in Muslim Contexts”, Sur: International Journal on Human Rights, 8(15): 7-33.

Kanunname-i Âli Osman: Sultan Süleyman Devri (1913). İstanbul: Ahmed İhsan ve Şurekâs1.

KORBATIEH, Souha (2018). "Adultery Laws in Islam and Stoning in the Modern World", Australian Journal of Islamic Studies, 3(2): 1-20.

MUTAF, Abdulmecit (2008). “Teorik ve Pratik Olarak Osmanlı'da Recm Cezası: Bazı Batı Anadolu Şehirlerindeki Uygulamalar”, Turkish Studies, 3(4): 573-597.

ÖZKORKUT, Nevin Ünal (2007). “İslam Ceza Hukukunda Kadın”, Ankara Üniversitesi Hukuk Fakültesi Dergisi, 56(2): 83-95. 
PEIRCE, Leslie (2003). Morality Tales: Law and Gender in the Ottoman Court of Aintab, California: University of California Press.

PETERS, Rudolph (2005). Crime and Punishment in Islamic Law: Theory and Practice from the Sixteenth to the Twenty-first Century. Cambridge: Cambridge University Press.

Qadi Register of Bâb Court, 54 (20), hüküm no: 537, 1102 (1691), 440.

Qadi Register of Istanbul Court, 25 (76), hüküm no: 312, 1179-1180 (1765-1767), 290.

SAMi, Yaku (1910). "Zinâ-Adulteré", İlm-i Hukuk ve Mukyâyese-i Kavânin Mecmuası, 1, (13): 508-509.

Selânikî Mustafa Efendi (1999). Tarih-i Selânikî II (1003-1008/1595-1600), haz. Mehmet İpșirli, Ankara: Türk Tarih Kurumu Yayınları.

SEMERDJIAN, Elyse (2006). "Gender Violence in Kanunnames and Fetvas of the Sixteenth Century", Beyond the Exotic: Women's Histories in Islamic Societies, ed. Amira el-Azhary Sonbol, Cairo: The American University in Cairo Press, 180-197.

KARAÇAY TÜRKAL, Nazire (2012). Silahdar Findıklılı Mehmed Ağa Zeyl-i Fezleke: 1065-22 Ca. 1106/1654-7 Şubat 1695, (Yayımlanmamış Doktora Tezi), Marmara Üniversitesi Türkiyat Araştırmaları Enstitüsü, İstanbul.

SONBOL, Amira (1997). "Rape and Law in Ottoman and Modern Egypt", Women in the Ottoman Empire: Middle Eastern Women in the Early Modern Era, ed. Madeline C. Zilfi, Leiden: Brill, 214-231.

SONBOL, Amira (2003). "Rise of Islam: $6^{\text {th }}$ to $9^{\text {th }}$ Century", ed. Suad Joseph, Encyclopedia Women \& Islamic Cultures: Volume I-Methodologies, Paradigms and Sources, pp. 3-9, Leiden ve Boston: Brill.

ŞENSOY, Naci (1942). “Zina Cürmü”, İstanbul Üniversitesi Hukuk Fakültesi Mecmuasi, 8(1-2): 73-100. Yayınlar1.

TEBLY, Karl (2013). Dersaadet'te Avusturya Sefirleri, çev. Selçuk Ünlü, Konya: Gençlik Kitabevi

TEMIZ, Yağmur (2014). “Türk İslam Hukukundan Günümüze Zina”, İnönü Üniversitesi Hukuk. Fakültesi Dergisi, 5(2)::489-514.

The Holy Qur'an (2004). Transl. Maulawi Sher 'Ali, Islamabad: Islam International Publications LTD.

The Ottoman Penal Code (1888), Transl. C. G. Walpole. Londra: William Clowes and Sons.

TUCKER, Judith E. (1998). In the House of the Law: Gender and Islamic Law in Ottoman Syria and Palestine, California: University of California Press.

TUCKER, Judith E. (2009). "Law and Gender", Encyclopedia of the Ottoman Empire, eds. Gábor Ágoston v\& Bruce Masters, pp. 325-328, New York: Facts on File.

ÜÇOK, Coşkun (1947). "Osmanlı Kanunnamelerinde İslâm Ceza Hukukuna Aykırı Hükümler III”, Ankara Üniversitesi Hukuk Fakültesi Dergisi, 4(1): 48-72.

Cie.

Wanda (1884). Souvenirs Anecdotiques sur la Turquie (1820-1870), Paris: Librairie de Firmin-Didot et

ZARINEBAF, Fariba (2010). Crime and Punishment in Istanbul, 1700-1800, Berkeley: University of California Press.

ZILFI, Madeline C. (2010). Women and Slavery in the Late Ottoman Empire: The Design of Difference, Cambridge: Cambridge University Press.

\section{Additional Recources}

B.O.A., A.\}MKT.MVL., 1/76, 27 Şevval 1261 (29 Ekim 1845).

B.O.A., A.\}MKT.MVL., 123/100, 25 Cemaziyelahir 1277 (8 Ocak 1861).

B.O.A., A.\}MKT.MVL., 2/94, 19 Şevval 1262 (10 Ekim 1846).

B.O.A., C..ADL., 19/1161, 8 Safer 1261 (16 Şubat 1845).

B.O.A., MVL., 68/55, 1 Şaban 1262 (25 Temmuz 1846).

B.O.A., ŞD., 2818/19, 4 Muharrem 1331 (14 Aralık 1912).

B.O.A., HAT., 512/25098, 2 Recep 1254 (21 Eylül 1838). 